\title{
Evidence for pre-Messinian submarine canyons on the Gulf of Lions slope (Western Mediterranean)
}

\author{
Johanna Lofi ${ }^{a,}$, and Serge Berné ${ }^{b, c}$ \\ a Géosciences Montpellier, University of Montpellier, 34095 Montpellier Cedex05, France \\ ${ }^{b}$ IFREMER, GM Technopôle Brest-Iroise, B.P. 70, 29280 Plouzané, France \\ ${ }^{\mathrm{c}}$ Université de Perpignan, Images, 66860 Perpignan Cedex, France \\ *: Corresponding author: J. Lofi, Tel.: +33 (0) 4686620 91; fax: +33 (0) 4686620 96, email \\ address : johanna.lofi@gm.univ-montp2.fr
}

\begin{abstract}
:
On the Gulf of Lions margin, the Messinian Salinity Crisis (MSC) event led to a significant and widespread erosion of the Miocene shelf and slope. It is thus difficult nowadays to restore the morphology of the margin at the beginning of the crisis, and to study the Middle-Upper Miocene series rarely preserved from erosion. In this study, thanks to the use of multichannel seismic reflection data from the Gulf of Lions western slope, it has been possible to image the Miocene slope deposits. Interpretation of the data reveals several diachronic sediment bodies just beneath the Miocene/Pliocene boundary. These bodies are related to slope erosional-depositional complexes, underlain by erosional unconformities outlined by seismic reflector truncations. They are $\mathrm{V}$ - or Ushaped in cross section. Over their mapped extent, these bodies are typically 8-12 km wide and incise up to 600 ms TWTT into the Miocene slope deposits. In plan view, they are roughly elongated NWSE, perpendicularly to the present day shelf break, and they progressively migrate towards the SouthEast. We interpret these seismic bodies as buried Miocene submarine canyons pre-dating the dramatic drawdown related to the MSC. In this study we try to constrain their age, and we discuss the events that may be at their origin. We also discuss the long-term impact of these slope canyons on the evolution of the margin.
\end{abstract}

Keywords: Submarine canyon; Miocene/Pliocene; Passive margin; Messinian salinity crisis 


\section{Introduction}

During the Messinian Salinity Crisis (MSC) (Hsü et al., 1973), the lowering in sea-level resulted in a significant erosion of the Mediterranean shelves and slopes (Ryan, 1976). In the Gulf of Lions, as everywhere in the Mediterranean, it is thus difficult to restore the morphology of the margin at the beginning of the crisis and to study the Middle-Upper Miocene series rarely preserved from erosion (Cravatte et al., 1974; Lofi et al., 2005). At the present time, an important morphological feature of the modern Gulf of Lions is the dense network of submarine canyons that deeply incise the continental slope (Berné et al., 1999) and that developed since the Middle-Late Pliocene (Lofi et al., 2003a). In this area, however, multichannel seismic profile interpretation allowed Lofi (2002) to evidence some singular seismic bodies located immediately beneath the Miocene/Pliocene boundary. Based on the strong basal erosional character and the poly-phased internal geometries of these bodies, this author suggested that they might correspond to buried Miocene paleo-submarine canyons. Nevertheless, because of the few seismic profiles available at that time, this interpretation remained subject to caution.

Submarine canyons play an important role in the transfer of the sediments from the coast to the deep basin. In the Mediterranean, offshore researches essentially concentrated on modern or predominantly Pliocene-Pleistocene examples (eg. Bourcart et al., 1948; O'Connell et al., 1987; Alonso et al., 1991; Bertoni and Cartwright, 2005). Older systems have been poorly studied, mainly because of low vertical resolution of seismic data, difficulties to have stratigraphic and lithologic controls and uncertainties in seismic interpretation of complex continental slope stratigraphy. In addition, to our knowledge, only few geophysical evidences exist for pre-Messinian submarine canyons on Mediterranean margins (eg. Levant margin (Druckman et al., 1994)). Until now, little attention has been paid to such incision events, their possible submarine origin and the possibility that they were reactivated as subaerial channels during subsequent lowstands such as the MSC drawdown (Druckman et al., 1994; Bertoni and Cartwright, 2006).

The present work focuses on the middle continental slope of the western Gulf of Lions (Fig.1). In this study, industrial multichannel data and multichannel seismic profiles collected by Ifremer provide locally good images of Miocene slope deposits. These data enable the production of a more accurate seismical and geomorphological analysis of these deposits. We are now able to discuss the nature and the age of the seismic bodies and to propose possible triggering events/mechanisms at their origin.

\section{Geological setting}

The study area is located on the western continental slope of the Gulf of Lions passive margin, SW France (Fig.1). The architecture of the margin is illustrated in figure 2-A.

At the bottom, a pre-rift basement has been structured in horsts and grabens during an OligoAquitanian rifting phase (Rehault et al., 1984). The overlying post-rift sequence experienced two distinct phases of outbuilding (Gorini et al., 1993) as a result of the MSC drawdown (Hsü et al., 1973; Ryan, 1976): during the Miocene and the Plio-Pleistocene (PP).

Despite the severe erosion on the margin during the MSC (Lofi et al., 2005), the location of the LateMiocene shelf-break has been approximated by some authors, on the basis of preserved paleo-shelf breaks observed locally on seismic profiles (Gorini, 1993; Lofi, 2002; Bache, 2003). This restoration nevertheless remains subject to caution because the pointed shelf-breaks were not dated precisely in the absence of adjacent boreholes. Recent work suggests that they are post Burdigalian-Langhian in age (Bache et al., 2003).

During the MSC, a dramatic fall in sea-level of at least $1500 \mathrm{~m}$ led to a widespread subaerial exposure of most of the Mediterranean margins (Ryan, 1973; Lofi et al., 2007). Thus, beneath the Gulf of Lions shelf and slope, the Miocene sequence is bounded above by a major unconformity: the Margin Erosional Surface (MES, Fig. 2-A). It's morphology reflects a buried drainage pattern (Gennesseaux and Lefebvre, 1980; Guennoc et al., 2000). This discordance correlates basinward to the thick Messinian evaporites of the Provençal basin and, in the downstream axis of the Messinian valleys, to 
some fan-shaped chaotic deposits interpreted as Messinian clastic units (Lofi, 2002; Lofi et al., 2005) (Fig. 1).

After the achievement of the MSC at $\sim 5.3 \mathrm{Ma}$, following a rapid marine transgression, the PlioPleistocene sediments prograded over the eroded Miocene margin (Fig. 2-A). Sediments were initially trapped in rias (Clauzon, 1973) and then progressively prograded to form the present-day shelf. The position of depocenters was strongly controlled by the topography inherited from the Messinian erosion (Lofi et al., 2003). Progradation was also partially controlled by faulted Miocene blocks reactivation (Duvail et al., 2005). As evidenced by Lofi et al. (2003), the first submarine canyons appeared only after 3.8 Ma, probably as a result of increased clinoform height, together with increased sea-level fluctuations and increased sediment supply from the surrounding mountains. Since the Middle-Upper Pliocene, most of the sediments were directly transferred towards the slope and the deep basin or accumulated in the buried canyons.

\section{Data and Methods}

Seismic data used in this study come from the CALMAR_1997 cruise acquired by IFREMER on the R/V L'Atalante. They consist of Gl-gun profiles shot at ten knots with a 6-channel streamer (Berné et al., 1999) post-processed with IFREMER's SITHERE software. Additional multichannel (24 channels) profiles were collected by IFREMER during the MARION-2000 cruise (on R/V Le Suroît). This data set has been completed by some other geophysical data (Ligo80 and Achère profiles) acquired by oil industry companies.

Over the study area, on the western Gulf of Lions slope, the seismic grid covers a total area of more than $1500 \mathrm{~km}^{2}$ with a mean spacing approaching $7 \mathrm{~km}$ (Fig. 1). Achère and Calmar96 seismic lines are of high quality compared to older oil-industry data such as the Ligo80 profiles. Because the available seismic lines displayed diverse resolution and/or signal penetration in the Miocene deposits, the studied features were not imaged with the same quality from one line to another, which increased the difficulty in mapping and correlating them precisely.

Analysis of the seismic data following a classical seismic stratigraphic procedure (in terms of stratal terminations, Mitchum and Vail (1977)) allowed the identification of seismic units and their boundaries. In this study, we especially focused on specific Miocene erosional boundaries and angular discordance visible over the study area.

\section{Seismic stratigraphic framework}

The general seismic stratigraphic framework of the study area is described with reference to one representative dip seismic section, parallel to the progradation direction of the margin (Fig. 2-C). Some of the seismic units and boundaries observed over the study area have been defined and labelled based on previous works:

We called "MES" the Messinian Margin Erosional Surface (Fig. 2), i.e. the discordant contact between the (ante-crisis) Miocene deposits and the overlying prograding Plio-Pleistocene sequence beneath the shelf and slope (eg. Lofi et al., 2007).

Following the labelling of Maillard et al. (2006), we called "BES" the Bottom Erosional Surface (Fig. 2), i.e. the discordant contact between the (ante-crisis) Miocene deposits and the syn-crisis deposits (i.e. Messinian clastics (CU) or deep basin messinian sequence (UU, LU, MU)).

The Messinian clastics (Lofi et al., 2005) have a characteristic chaotic seismic facies and correspond to unit "CU" ( for "Chaotic Unit").

In this study, some other major erosional surfaces have been evidenced below the MES, in the Miocene deposits. They were labelled "ES1" to "ES5" from the oldest to the most recent. These surfaces underlain 5 distinct sediment bodies that have been respectively labelled "C1" to "C5". The seismic characteristics of these bodies are detailed in section 5.2. 


\section{Results}

\subsection{Overall Miocene to modern sedimentary architecture over the study area}

Over the study area, the architecture of the Miocene-to-modern deposits is illustrated on the dip seismic line drawing presented in figure 2-B:

At the top, the Plio-Pleistocene sequence (PP) is up to $1.5 \mathrm{sec}$ TWTT thick in this area. It displays numerous recent and buried submarine canyons (Berné et al., 1999; Berné et al., 2004; Baztan et al., 2005). This post-Messinian sequence overlies either the MES or, when present, CU. Down-slope, the Plio-Pleistocene sediments are faulted and disorganised (eg. Fig. 2-B, kms 105-115) due to Messinian salt retreat.

At the base of the Plio-Pleistocene sequence, the MES is relatively smooth and does not display high relieves (Fig. 3). The study area and most of the Miocene seismic bodies studied here are located beneath a promontory separating two main Messinian drainage systems: the Languedoc-Roussillon Messinian valley to the East and the Rascasse valley to the West (Lofi et al., 2005). Both valleys are filled with probable Messinian clastics (CU, Figs. 1, 3 and 4). Where the thickness of CU exceeds -150 msec TWTT, a seismic transition is frequently observed from a high-amplitude chaotic facies (CU S.s.) to a more transparent chaotic facies below (eg. Fig. 2-C). We interpret such a vertical transition as resulting from the attenuation/diffraction of the acoustic signal through the Messinian clastic deposits. This phenomenon considerably limits the potential for effective interpretation and mapping from existing data beneath $\mathrm{CU}$.

Below the MES, Miocene deposits displaying seismic onlap, truncation and/or incision are observed in environments ranging from paleo-shelf to lower slope/basin. Clinoforms are observed on some dip seismic lines (Fig. 2). Seismic horizons exhibit a clearly recognisable main physiographic break in slope in the depositional profile between the foresets and topsets (Fig. 2-C), which corresponds to the offlap break of Vail et al., (1991). In this study, we have pointed on the dip seismic lines the most seaward offlap break. Figure 2 illustrates the presence of such an offlap break close to kilometre 90, just beneath an erosional surface labelled ES2. This offlap break thus represents the location of a paleo-shelf break older than ES2. It has been mapped on figure 5 and was located $\sim 30 \mathrm{~km}$ seaward of the present day shelf break (Fig. 2). The precise age of this shelf break is unknown at the present time.

Below the MES, in the Miocene sequence, 5 distinct seismic bodies ( $\mathrm{C} 1$ to $\mathrm{C} 5$ ) underlain by major erosional surfaces are observed (Figs. 2, 3 and 4). They are presented with more details in section 5.2 .

\subsection{Characteristics of the Miocene seismic bodies C1 to C5}

\subsubsection{Lower erosional boundaries ES1 to ES5}

Beneath the MES, the architecture of the Miocene interval displayed by seismic profiles is rather complex, with evidence of discontinuities. Interpretation of the Miocene deposits thus allows for the identification of a number of distinct seismic bodies bounded by erosional surfaces (ESs). Five ESs were identified as reasonable seismic boundaries for mapping purposes on the basis of their much greater lateral continuity. They have been labelled ES1 to ES5 from the oldest to the most recent. These ESs are essentially outlined by truncations of the underlying seismic reflectors (Figs. 2-C and 3). However, reflector geometry and/or seismic facies changes are also locally observed on both sides of the ESs (Fig. 3, ES2). These surfaces can be traced as surfaces of truncation across the Miocene sequence (Fig. 5). However, they cannot be followed over the whole study area because of: (1) the broad spacing of the seismic grid; (2) the disparate resolution of available seismic profiles; (3) the subsequent Messinian erosion (Fig. 3, shot point 2500 ) and (4) the transparent chaotic facies observed beneath the Messinian clastics (CU).

\subsubsection{Internal seismic facies and geometries}

We mapped 5 main seismic bodies labelled $\mathrm{C} 1$ to $\mathrm{C} 5$ bounded at their bottom by erosional surfaces ES1 to ES5, respectively. Five key seismic facies have been recognised within these bodies based on 
the amplitude, continuity, and geometry of the internal seismic reflectors. These seismic facies are presented in figure 5 :

Facies A: chaotic, generally transparent.

Facies B: chaotic with complex, truncated or inclined geometry.

Facies C: low-amplitude, (sub-)continuous, sub-parallel.

Facies D: high-amplitude, (sub-) continuous, sub-parallel.

Facies E: high-amplitude, continuous, wavy.

Detailed mapping of these facies was not possible with the available data set. In addition, a part of the spatial variability appears directly related to the quality of the data and to the resolution of the seismic profiles. However, an overall distribution pattern is clearly observed. On seismic lines acquired in the central and southern parts of the study area (e.g. Fig. 6), most of the studied systems show relatively well organised groups of continuous to sub-continuous reflections (Fig. 7, facies C, D, E). Intercalated transparent levels are visible locally (eg. Fig. 3, within system C3). On seismic lines acquired in the northern part of the study area (eg. Figs. 7 and 8), internal seismic facies are rather different: groups of reflections are poorly organised with an overall chaotic character (Fig. 7, facies A, B). This distribution pattern seems related to the geographic position of the system with respect to shelf/slope depositional environments.

Where internal reflectors are visible and continuous (Fig. 7, facies C, D, E), reflector geometry changes with the orientation of the seismic lines. In cross sections, the erosional systems show internal reflectors that mostly onlap against the erosional surfaces ESs (Fig. 6). In dip section, some downlap reflectors are observed over the basal unconformity ES, suggesting a gently basin-ward progradation tendency (Fig. 3, system C3). In dip section, the internal reflection pattern generally consists of gently dipping seaward reflections illustrating downslope prograding features (Fig. 4).

\subsubsection{Morphological characteristics}

Figure 5 shows a possible spatial extension of the seismic bodies in plan view. The accuracy of this map however remains subject to caution because the position of the eastern walls of $\mathrm{C} 3, \mathrm{C} 4$ and $\mathrm{C} 5$ are not precisely determined (Figs. 5 and 6). These speculated limits are drawn in dotted lines in figure 5. Despite these uncertainties, the general morphology of these systems resemble large infilled valleys, globally orientated NW-SE with axes sloping seaward. The top of each of them is truncated either by the MES, the BES and/or by another (younger) seismic body (Figs. 3, 4 and 6 ). Reflections within lateral "walls" are also truncated, clearly indicating erosion. C1 to C5 are described below:

\section{System C1}

C1 has only been mapped in the northern part of the study area (Fig. 5). Figure 7 shows a strike section of this body, which is delineated by ES1 showing a clear erosional character and a valley-like morphology. The eastern limit of $\mathrm{C} 1$ is speculative because it extends beneath $\mathrm{CU}$ where the acoustic signal is disturbed (Fig. 7, shot points 1250-1700). Over its mapped extent, C1 reaches up to 600 msec TWTT in thickness (Fig. 8), and at least $8 \mathrm{~km}$ in width. The depth of axial incision of C1 increases downslope, from 2.9 upward to $3.25 \mathrm{sec}$ TWTT. The internal seismic facies of $\mathrm{C} 1$ is rather chaotic with discontinuous reflectors dipping towards the NE in strike section (Fig. 7). An angular discordance is visible locally, on the eastern flank of the system.

\section{System C2}

C2 is strongly erosional in cross section (Fig.8) and has a clear erosional upslope lower limit (Fig. 2C). It is delineated by ES2 and has been mapped in the north-western part of the study area (Fig. 5). $\mathrm{C} 2$ extends basinward either beneath $\mathrm{C} 3$ or beneath $\mathrm{CU}$. In both cases, limit of extent can only be speculated or indirectly estimated. C2 reaches more than $300 \mathrm{msec}$ TWTT in depth and $8 \mathrm{~km}$ in width over the mapped area. Where imaged, internal reflection continuity varies from discontinuous to chaotic or transparent. In strike sections, the internal organisation of the seismic reflectors is complex and is characterised by slightly inclined, laterally converging, diachronic $\mathrm{v}$-shaped reflector packages (Fig. 8). This suggests that several phases of erosion occurred, coupled with a lateral (westward) migration of the whole system. In dip section, C2 contains discontinuous reflections dipping seaward and downlapping the basal unconformity ES2, suggesting a gently basin-ward progradation tendency (Fig. 2-B). In both dip and strike section, C2 also exhibits a clear aggradational geometry in the topset region (Figs. 2-C and 8). 


\section{System C3}

$\mathrm{C} 3$ is one of the largest and most recognisable seismic body that has been mapped. This system is underlain by ES3 (Fig. 3). C3 extends over the Miocene interfluve separating the LanguedocRoussillon and the Rascasse Messinian valleys (Figs. 5 and 6). Over its mapped extent, C3 reaches more than $500 \mathrm{msec}$ TWTT in thickness and $14 \mathrm{~km}$ in width and can be traced downslope for $20 \mathrm{~km}$ until it is truncated by the MES (eg. Fig. 3, shot points 1500-2500). The maximum depth of ES3 reaches at least $3.5 \mathrm{sec}$ TWTT basinward (Fig. 6). The lateral limit of this system locally extends beneath the Messinian clastics CU and has not been mapped in this area (Fig. 4, shot points 11001300). In addition, its westward extension is speculative (Fig. 6). Where imaged, the main internal seismic facies is composed of relatively well organised groups of continuous to sub-continuous, subparallel reflections (Fig. 6). Intercalated transparent or chaotic levels are also visible locally (Figs. 3 and 4). In cross section, most of the continuous internal reflectors onlap against the erosional unconformity ES3 (Fig. 6). Some reflectors downlapping on ES3 are also observed (Fig. 3).

\section{System C4}

C4 extends over the Miocene interfluve (Fig. 5) and is superimposed to C3 as illustrated in figures 4 and 6. This system is delineated by ES4 displaying an irregular, undulated geometry. The eastern limit of C4 has not been mapped, mainly because of the low quality of the data in this sector (Fig. 6, shot points 700-900) and because of the presence of CU. Over its mapped extent, the maximum measured depth reaches 400 msec twwt. Where imaged, the internal seismic facies is composed of relatively well organised groups of continuous to sub-continuous, sub-parallel reflections. Zones of wavy seismic reflectors are observed locally (Fig. 3).

\section{System C5}

C5 has been mapped in the south-eastern part of the study area (Fig. 5). It is bounded below by ES 5 which reaches a depth $3.2 \mathrm{sec}$ TWTT in figure 6. Figures 4 and 6 illustrate the irregular morphology of ES5 characterised by several narrows valley-shaped, localised areas of incision. Internal seismic facies is composed of relatively well organised groups of continuous to sub-continuous, sub-parallel reflections. Onlaps against ES5 are visible in cross section. Several minor internal unconformities are locally observed within C5. These internal unconformities (evidenced by internal truncated reflectors, downlaps, toplaps and onlaps) apparently separate several generations of erosion within the same seismic body (Figs. 4 and 6).

Because of the large spacing of the seismic lines, the heterogeneity of the data and the presence of the MES and of $\mathrm{CU}$, the lateral extension of these bodies has been mapped with moderate confidence. Some uncertainties remain locally. For example, the most eastward seismic body extending beneath unit $\mathrm{CU}$ (Fig. 5) has not been tied with confidence to the surrounding bodies (Fig. 6). Based on the morphology and erosional depth, we correlated it to C3, but it may belong to another body. A more precise mapping would require additional high quality seismic data. The eastward extension of systems $\mathrm{C} 3, \mathrm{C} 4$ and $\mathrm{C} 5$ is also matter of speculation as mapping beneath the Messinian detritals remains problematic (Figs. 5 and 6).

Despite these uncertainties, we are confident concerning the global trend and relative stratigraphy of our mapping. We also consider that our data is representative of the geometry/organisation of the systems over the mapped area. Relative chronology of the succession from the oldest body (C1) to the most recent (C5) is easily inferred (Fig. 5): C2 passes laterally above C1 (Fig. 8); C2 extends beneath C3 (Fig. 3) and C3, C4 and C5 are respectively imbedded (Figs. 3 and 6). As evidenced on figure 5 , the mapping of the Ess indicate a succession of erosional events displaying a global southeastward migration in time.

Mapping of these systems also shows that erosional features $\mathrm{C} 1$ to $\mathrm{C} 2$ extend partly to the region located landward from the mapped Miocene offlap breaks (Fig. 5). C1 and C2 thus appear to cut back into the topsets region of the progradational system located below (Fig. 5). Erosional surfaces ES1 and ES 2 cannot be traced basinward (Figs. 2-C and 3, C2 eroded by C3). Their morphology in cross section however suggests a localised (narrow) erosion in their headward extremities (Figs. 7 and 8 ). 


\section{Interpretation}

\subsection{Evidences for submarine canyon systems}

Seismic bodies C1 to C5 have been mapped in the vicinity or just seaward of the offlap break region mapped in figures 2 and 5 . In the context of a gently prograding margin, this suggests that their development is related to slope (or outer-shelf) erosional/depositional processes. Seismic patterns above the basal ESs present similarities with similar features described in the literature (eg. McHargue and Webb, 1986; Williams et al., 1998; Gardner et al., 1999). leading to two rather different hypotheses. The seismic bodies were formed either by (1) large-scale landslides or (2) by submarine canyons that developed on the Miocene slope, and were successively filled by sediments. In other terms, the erosional surfaces ESs might correspond to regional sliding surfaces and/or to canyon-cut surfaces.

\subsubsection{Submarine landslides}

The first hypothesis falls on gravity deformation. Interpretation of a predominant landslide origin is generally based on the evidence for essential features such as a rupture surface associated to a headwall scarp, a displaced mass of sediment and a toe (Varnes, 1978). Generally, landslides are also characterised by broken, contorted, and tightly folded formerly continuous, parallel beds. This usually results in chaotic internal seismic facies. The displaced mass might nevertheless remain intact or slightly deformed (Watkins and Kraft, 1978). Here, the studied seismic bodies have been partially eroded during the Messinian and cannot be mapped beneath $\mathrm{CU}$. Consequently, if any headwall scarp and toe ever existed, they are no longer visible and cannot constitute a discriminating argument. ES3 has a concave upward and scoop-shaped morphology (Fig. 3), and could be interpreted as the rupture surface of a slide (Hampton, 1996; McAdoo et al., 2000). System C3 could thus enter a category of submarine landslide with minor scarps or broken beds within what could be the displaced mass itself. However, similar-appearing features can also be produced by other processes such as submarine canyon fills, and the concave-like shape of C3 is not observed in other systems. C5 for example presents an irregular wavy lower ES5 (Fig. 4). In addition, the landward extremity of system C2 that has been preserved from the Messinan erosion does not show evidence for a headwall scarp (Fig. 2C).

\subsubsection{Submarine canyons}

The thickness of seismic bodies C1 to C5, as well as their very distinct basal erosional boundaries (ESs) led us to conclude that they very likely correspond to a series of buried submarine paleocanyons, i.e. to erosional/depositional complexes. In that case, the surfaces of truncation would correspond to submarine canyon walls and floors. In addition,, the general NW-SE great axis of these successive sediment bodies, as well as their progressive migration in a SE direction, support the scenario of canyon incisions progressively infilled as the shelf edge migrates in a seaward direction, as a result of margin growth. ESs are thus considered to be canyon-fill seismic facies envelopes. This interpretation is supported by the erosional character of these surfaces that are locally irregular, curved and undulating (eg. McHargue and Webb, 1986; Bertoni and Cartwright, 2003; Olabode and Adekoya, in press) and by their valley-like morphology, $U$ to $V$ - shaped in cross section, globally elongated NW-SE and sloping basinward to the south-east (Fig. 8).

Seismic reflections above ESs are thus interpreted as formed by infill deposits. C3 to C5 contain fairly continuous seismic reflections that terminate against their erosional flanks (eg. Figs 3 and 6). Such an internal geometry is interpreted as an onlapping-fill geometry (Fig. 6). Aggradational packages of lowamplitude, more or less continuous, reflections that lap onto the canyon walls have already been interpreted from seismic profiles as the product of phases of canyon-fill (eg. Galloway et al., 1991; Williams et al., 1998). Here, canyon fills may consist entirely of continuous, nearly parallel seismic reflections. Such a facies has been observed in some recent submarine canyons of the Gulf of Lions that have been partially infilled (eg. Baztan et al., 2005). Canyon fills however may also alternate with zones of wavy seismic reflections as observed in C4 (Fig. 3). It must be noted that C1 and C2, mapped in the north part of the study area, show a much more chaotic internal facies (Fig. 5, A and B). Continuous reflectors are rare. As shown in figure 5, C1 and C2 partly extend to the region located landward of the Miocene paleo-shelf break (mapped from figure 2). They cut back into the topset 
region of a Miocene progradational system, as clearly shown in figure 2-B at kilometre 80. On figures 7 and $8, \mathrm{C} 1$ and C2 are narrow V-shaped in cross section. They incise Miocene topsets and are thus interpreted as canyon-head features. This interpretation is supported by the following observation: 1 ) in dip section, C2 contains a set of sub-horizontal reflectors interpreted as topsets (Fig. 2-C). These topsets correlate with dipping seaward discontinuous reflectors interpreted as clinoforms. This clinoform geometry is clearly visible on the dip profile in figure 2-C and can be interpreted as the progressive filling of the canyon head by progradation from the upslope region (Mountain et al., 1996); 2) in strike section, C2 also contains some diachronic v-shaped reflector packages (Fig. 8) that strongly resemble images of lateral accretion within a canyon head, as described by McHargue and Webb (1986). We thus observe an overall progradation, together with westward migration of the canyon head, as it is progressively filled from the upslope/shelf break region. This might reflect a general anti-clockwise circulation in the Gulf of Lions during the Miocene, as presently observed (Millot, 1999).

The head region of the canyons is clearly imaged only for system C2. No other seismic dip section displays the head region of any other canyon, thus stressing the indirect character of our interpretation for canyons C1, C3, C4, and C5, through the analogy with C2.

In summary, we propose that seismic bodies $\mathrm{C} 1$ to $\mathrm{C} 5$ evidenced in this study correspond to infilled paleo-submarine canyons formed by a series of successive cut and filled phases. The internal unconformities observed within the filling of C2 (Fig. 8) and C5 (Fig. 4) would thus separate several internal generations of cut and fill. The truncated reflectors seem to indicate that sedimentation was periodically disrupted by renewed erosion down to the axis of the canyon. The poly-phased character of these bodies strongly support the hypothesis of the submarine canyon origin as paleo-submarine canyons currently present a number of phases of deposition and erosion that can be controlled, among others, by fluctuations in relative sea-level (eg. Baztan et al., 2005). Analogy with infilled PP canyons on the same margin from similar data set and/or from previous studies support our interpretation (eg. Fig. 4 in Baztan et al., 2005).

According to classifications based on the internal seismic expression of the canyon-channel-levee system (Normark, 1970; McHargue and Webb, 1986), the seismic data presented here correspond to the degradational (possibly transitional) sectors (i.e., in the outershelf/upslope area) of the canyons. This suggest that large channel-levees and submarine fans, if they exist, would be expected in a more distal area, beneath $\mathrm{CU}$ or beneath the Messinian deposits in the deep basin (Fig. 2). This hypothesis cannot be tested with our dataset, because of the lack of resolution of the data or because the seismic signal cannot penetrate deeply enough beneath the Messinian clastics CU and/or the deep basin Messinian sequence .

If Miocene submarine canyons were not previously described in the Gulf of Lions, Middle- to UpperMiocene submarine canyons have been described on several Atlantic margins (eg. Mountain et al., 1996). However, they are less abundant, smaller and narrower compared to their modern or PlioPleistocene equivalents on the same margin. In the Gulf of Lions, submarine canyons are prevalent on the modern and Plio-Pleistocene slope. Over the study area, Miocene canyons however also appear abundant with respect to the extension of the study area.

\subsection{Age of the submarine canyons}

The studied paleo-submarine canyons are part of a Miocene prograding shelf/slope sediment prism that cannot be traced landward (and tied to the boreholes drilled on the shelf) because its landward extension has been totally eroded during the Messinian event (Fig. 2). Thus, the age of the submarine canyons can only be approximated. Some observations and lines of reasoning can help narrowing the potential time window (Fig. 9).

\subsubsection{Upper limit}

Seismic data clearly show that all of the studied submarine canyons have been partially eroded during the MSC. The MES is a complex, polygenic and diachronic surface in the Gulf of Lions (Lofi et al., 2005). Its formation started around 5.6 Ma with the beginning of the Mediterranean drawdown (Gautier et al., 1994; Krijgsman et al., 1999) and ended with its "fossilisation" around $5.32 \mathrm{Ma}$. This fossilisation results from a rapid transgression marking the return of open marine conditions in the Mediterranean 
at the end of the crisis (and the achievement of subaerial erosion over the study area). The downlap of the Lower Pliocene bottomsets on the MES attests of this rapid re-flooding at the geological scale (Lofi et al., 2005). C1 to C5 are thus undoubtedly older than $5.32 \mathrm{Ma}$.

We also propose that canyon initiation occurred before 5.6 Ma (before the beginning of the Messinian drawdown) because the formation of submarine canyons during such a major regression is hardly compatible with: (1) the aggradational geometry of the topsets observed in C2, on both strike and dip sections (Figs. 2-C and 8) and (2) the filling and preservation of 5 successive generations of submarine canyons. As suggested by Lofi et al. (2005), the study area was probably constituting a topographic high (interfluve of the Rascasse and Languedoc-Roussillon Messinian valleys (Fig. 1)) during the MSC lowstand. This remarkable area has thus been relatively preserved from Messinian erosion compared to the rest of the Miocene slope, allowing the preservation until now of the preexisting Miocene submarine canyons.

\subsubsection{Lower limit}

Recent seismic stratigraphy studies (Bache, 2003; Bache et al., 2003; Gorini et al., 2003) allow to approximate the initiation of canyons. These authors tied Miocene horizons of the Gulf of Lions to data from boreholes situated on the shelf and upper slope (see Fig. 1 for location of the boreholes). Information from the drilling reports were rather limited and the position of the Miocene stratigraphic boundaries thus remains uncertain. However, analysis of planktonic and benthic foraminifera on some wells (Cravatte et al., 1974) brought additional information concerning depositional environments. Thus, beneath the shelf and beneath the study area, Bache et al. (2003) and Gorini et al. (2003) recognised a remarkable Miocene seismic reflector constituting a downward shift surface bounding a depositional sequence. This reflector is at the present time located far beneath the submarine canyons evidenced in this study and is assigned by Bache et al. (2003) to the Lower to Middle Miocene. This thus allows to narrow down the lower limit of the potential time window for canyon development, and to propose a Langhian to Upper Messinian age (i.e. between 16.4 and $5.6 \mathrm{Ma}$ ) for the first appearance of submarine canyons in the western Gulf of Lions (Fig. 9).

\subsection{Possible triggering factors}

There is no single explanation for the origin of various types of submarine canyons described around the world (Shepard, 1981), and we will review briefly the main processes invoked, keeping in mind that the combination of several factors is also possible.

\subsubsection{Slope failure}

The most common process responsible for canyon initiation is considered to be slope failure, followed by erosion progressively migrating upslope (Twichell and Robert, 1982) or downslope through successive erosional events (Pratson and Coakley, 1996). In this scenario, turbidity currents are generally considered as responsible for the ensuing excavation of the canyons, allowing to maintain and enlarge pre-existing slope incisions.

\subsubsection{Eustatism}

In the Gulf of Lions, it has been proposed that the activity of Pleistocene canyons depended upon the connection of their head with a fluvial system during lowstands, at the origin of axial incision (Baztan et al., 2005). This incision, in return, can be at the origin of canyon enlargment by destabilization of its rims (Sultan et al., 2007). This scenario is in general agreement with the classic sequence stratigraphic model, which predicts canyon incision during lowstands (Vail et al., 1991). Middle to Late Miocene erosional events have been described on several Atlantic margins such as the New Jersey (Miller et al., 1987; Fulthorpe et al., 1996; Moutain et al., 1996), with evidences for a glacio-eustatic control (Fulthorpe et al., 2000). Studies onland also support the eustatic hypothesis for canyon appearance. The importance of eustatic control has also been demonstrated onshore of our study area, where a succession of fluvial incisions is observed in the Miocene deposits of southern Alps (Besson et al., 2005; Besson, 2005). These authors show that these incision phases are associated to eustatic lowering enhanced by local tectonics: three major incisions are dated from the Aquitanian/Burdigalian transition, the Latest Burdigalien and the Serravalian/Tortonian transition. 
Because the first two phases pre-date our time window (Fig. 9), the period of canyon initiation should correspond to the third phase, which in fact corresponds to the most pronounced sea-level fall that occurred at the Serravalian/Tortonian transition (TB3.1 cycle (Haq et al., 1987), Fig. 9). Other regressions that occurred since the Middle-Miocene could also play a role in canyon initiation and/or rejuvenation. For instance, Maillard and Mauffret (2006) have identified in the Valencia basin a sealevel lowstand occurring immediately prior to the MSC drawdown, with an estimated Late Tortonian, Early Messinian age. However, the Serravalian/Tortonian hypothesis is more appealing as it corresponds to the most pronounced draw-down prior to the MSC, with a magnitude of more than $100 \mathrm{~m}$, probably sufficient for allowing fluvial connection with the continental slope, a condition required in the scenario of axial incision of Baztan et al. (2005).

\subsubsection{Upper Miocene Tectonics}

In the western shelf of the Gulf of Lions, Mauffret et al. (2001) showed that the Miocene sequence is offset by a number of normal faults (Mio, Fig.2-A), associated with an extensional phase dated from the Late Miocene. This event led to the creation of a large anticline structure whose axis is on the south-western outer shelf area (Fig. 2-A, km 42), in the offshore continuation of Cap Creus. Although this roll-over was subsequently eroded during the Messinian event, the location of its axis has been restored by Lofi et al. (2005). Our study area is situated 40-45 km southward, on the southern flank of the anticline (Figs. 1 and 2-A). It is possible that during this tectonic event, large slides and slope failures developed on the Miocene slope, and subsequently evolved into submarine canyons. This may have been coupled with an increase in clastic sediment supply to the basin, as a result of the Serravalian/Messinian tectonic uplift of the border massifs of the Gulf of Lions (eg. Clauzon et al., 1987; Seranne et al., 2002). In the Western Mediterranean, Upper Miocene submarine incisions of the Afiq canyon have probably been initiated by slope failure during the Lower Tortonian (Druckman et al., 1995).

In order to decipher the tectonic and eustatic origin of canyons, we should look for the existence of sub-marine canyons on the eastern Gulf of Lions Miocene slope which was not affected by Upper Miocene tectonic extension. However, it is not clear that such submarine canyons, if they existed, were preserved from the Messinian erosion.

Other factors such as a climaticaly-induced increase of sediment supply, leading to over-steepening of the upper slope, may also have plaid a role in controlling canyon formation and evolution on the margin. Without borehole data, no definitive conclusion can be made as to their origin.

\subsection{Long-term implications}

The existence of Miocene canyons raises some interesting questions regarding whether and how they link to the Messinian subaerial valleys and to the Plio-Pleistocene submarine slope canyons on the same margin. Onshore, in the Miocene Molasse Basin of the southern Alps, Besson (2005) observed that the latest fluvial incisions (Tortonian) are often re-incised by the Messinian network. Thus, when viewed in light of the potential time window for the submarine canyon development on the Miocene slope (between 16.4 and 5.6 Ma), we may consider that those canyons might have played a significant role in controlling the accommodation space of the overlying deposits and/or that they might have acted as preferential sites of reactivation as subaerial channels during the subsequent MSC lowstand. This interpretation is supported by the fact that both the mapped slope canyons and Messinian rivers roughly display the same NW-SE orientation. We also observe a global eastward migration of the submarine canyon systems (Fig. 5). Extrapolating this tendency, we can assume that during the MSC drawdown phase, the Languedoc-Roussillon Messinian rivers may have re-incise a submarine canyon pathway located westward of our study area.

On the slope, the Messinian river network may thus have been partially controlled by the morphological/sedimentological context, whereas on the shelf a clear tectonic/structural control that has been evidenced (Lofi et al., 2005; Gorini et al., 2005).

The importance of Upper-Miocene pre-existing canyons for understanding the depositional and erosional processes active during the MSC has already been demonstrated in the Eastern Mediterranean (Bertoni and Cartwright, 2006). As described by these authors on the Levant area, some Oligo-Miocene submarine canyons acted as preferential sites of erosion in the earliest stages of 
the MSC. This created a locally irregular geometry of the edge of the evaporites, characterised by major embayments of the evaporitic system. In the Gulf of Lions, however, we have no direct evidence that the pre-Messinian submarine canyons were still active in the earliest stages of the MSC. This is essentially due to the large uncertainty about their age, and to the presence of Messinian clastics deposits on the slope that considerably limit the potential for effective interpretation of pre-MSC deposits. Some embayements of the evaporites are however visible (Fig. 1) but they are locally controlled by deep structures (Oligo-Aquitanian transfer zones; Dos Reis et al., 2005). The fact that the study area was probably constituting a topographic high (interfluve of the Rascasse and Languedoc-Roussillon Messinian valleys (Fig. 1)) during the MSC lowstand would explain the embayment of the salt on both sides of this area (lowest topography in the axis of the valleys). This remarkable area has thus been relatively spared from the Messinian erosion compared to the rest of the Miocene slope, allowing the preservation until now of the pre-existing Miocene submarine canyons.

Other investigations dealt with the morphological and structural features influencing the depositional context of the evaporites. Control on Messinian deep basin evaporites (and detrital deposits) by the pre-existing morphology has also been observed on the western Mediterranean Sardinia margin, in the Oristano amphitheater (Sage et al., 2005).

Another question is to determine whether the pre-Messinian slope canyons are linked or not to the post-Messinian canyon systems in the area. An important morphologic feature of the modern Gulf of Lions is the dense network of submarine canyons that deeply incise the continental slope. However, on the western part of the margin, there is no evidence for genetic link between subaerial Messinian canyons and post-Messinian submarine canyons (Berné et al, 1999; Berné and Gorini, 2005). PostMessinian submarine canyons indeed formed progressively since the Middle-Late Pliocene, probably in relation with increasing sea-level changes and sediment supply, combined later with an increased clinoform height possibly due to a change in the gradient of the underlying Messinian surface (Lofi et al., 2003).

\section{Conclusion}

In the Gulf of Lions, an overall high subsidence and sedimentation rate during the Miocene led to the construction of a thick and wide continental shelf. During the Messinian, the lowering of sea-level resulted in significant erosion of the Miocene shelf and slope. It is thus difficult nowadays to restore the morphology of the margin at the beginning of the crisis, and to study the Middle-Upper Miocene series rarely preserved from erosion. Interpretation of multichannel seismic reflection profiles provides new information for the understanding of the history, stratigraphy and sedimentary dynamics over the western Gulf of Lions during the construction of Middle-Upper Miocene margin. The most important observations are as follow:

Several diachronic, superimposed, seismic bodies are visible on the Middle-Upper Miocene slope, beneath the Messinian erosional surface. On the basis of their internal architecure, morphology and spatial organisation, these bodies are interpreted as paleo-submarine canyons. Miocene channellevee systems and/or lobes are therefore expected in a seaward direction, beneath the continental rise or above the abyssal plain, possibly beneath the Messinian deep basin sequence.

We propose that the origin of the submarine canyons pre-dates the initiation of the Messinian drawdown phase dated at $\sim 5.6 \mathrm{Ma}$ and that the first occurrence of submarine canyons occurred during the Middle-Upper Miocene, rather than during the Middle-Upper Pliocene, as previously though. The appearance of these canyons may be related to one, or the combination, of several factors among which: (a) the occurrence of fluctuations in sea level after 16.4 Ma (especially the pronounced sea-level fall that occurred at the Serravalian/Tortonian transition) and (b) a local tectonic event on the western platform. Considering observations onshore (Besson, 2005), the lower Tortonian sea-level fall appears as the best candidate for canyon initiation. However, in the absence of a precise chronostratigraphic control, we cannot reach conclusive evidence concerning their origin.

Middle-Upper Miocene canyons might have played a significant role in controlling the accommodation space of the Messinian deposits and/or might have acted as preferential sites of reactivation as subaerial channels during the subsequent MSC lowstand. On the slope, a 
morphological/sedimentological control on the Messinian river path may thus have occured, whereas a tectonic/structural control prevailed on the shelf.

\section{Acknowledgements}

This work is part of the GDR "Marges" French research program (contribution no. 2177). S.B. obtained additional support from Agence Nationale de la Recherche (ANR, contract NT05-3-42040).

We thank TOTAL for providing seismic lines in the framework of this program. The authors wish to thank Simon Barry for his invaluable assistance with english. We acknowledge the editor-in-chief, Prof. D.G. Roberts, for advice to the manuscript. Special thanks to the journal reviewer, C. Bertoni, who improved the manuscript through very constructive comments on reviewing the manuscript.

\section{References}

Alonso, B., Canals, M., Got, H., Maldonado, A., 1991. Sea valleys and related depositional systems in the Gulf of Lions and Ebro continental margins. American Association of Petroleum Geologists Bulletin 75 (7), 1195-1214.

Bache, F., 2003. Etude du Miocene du Golfe du Lion: description des unités sismiques, évolution de la marge. Diplôme d'Etudes Approfondies, University of Lille I, 52pp.

Bache, F., Gorini, C., Olivet, J-L., Rabineau, M., Duvail, C., Lestrat, P., Lofi, J., Mauffret, A., 2003. The Miocene of the Gulf of Lions (France): description of seismic units and margin evolution., Ocean Margin Research Conference, Paris, pp. 115.

Baztan, J., Berné, S., Olivet, J-L., Rabineau, M., Aslanian, D., Gaudin, M., Réhault, JP., 2005. Axial incision the key to understand canyon evolution (in Submarine canyons of the western Gulf of Lions). Marine and Petroleum Geology 22, 845-863.

Berné, S., Loubrieu, B. et l'équipe embarquée, 1999. Canyons et processus sédimentaires récents sur la marge occidentale du Golfe du Lion. Premiers résultats de la campagne Calmar. Comptes Rendus de l'Académie de Sciences 328, 471-477.

Berné, S., Carré, D., Loubrieu, B., Mazé, J.P., Morvan, L., Normand, A., 2004. Le Golfe du Lion, Carte morpho-bathymétrique ; IFREMER, Brest 2004.

Berné, S., Gorini, C., 2005. The Gulf of Lions: An overview of recent studies within the French 'Margins' programme. Marine and Petroleum Geology 22 (6-7), 691-693.

Bertoni, C., Cartwright, J., 2003. 3D seismic analysis of slope-confined canyons from the PlioPleistocene of the Ebro Continental Margin (WesternMediterranean). Basin Research 17, 43-62.

Bertoni, C., Cartwright, J., 2005. Headless submarine canyons on the Ebro margin of eastern Spain. Basin Research, 17, 54-72.

Bertoni, C., Cartwright, J., 2006. Controls on the basinwide architecture of late Miocene (Messinian) evaporites on the Levant margin (Eastern Mediterranean), Sedimentary Geology, 188-189, 93-114.

Besson, D., 2005. Architecture du bassin rhodano-provençal miocène (Alpes, SE France) : relations entre déformation, physiographie et sédimentation dans un bassin molassique d'avant-pays. Thèse de Troisième Cycle, ENS des Mines de Paris, 365pp.

Besson, D., Parize, O., Rubino, J.-L., Aguilar, J.-P., Aubry, M.-P., Beaudoin, B., Berggren, W.A., Clauzon, G., Crumeyrolle, P., Dexcoté, Y., Fiet, N., laccarino, S., Jiménez-Moreno, G., Laporte-Galaa, C., Michaux, J., Von Salis, K., Suc, J.-P., Reynaud J.-Y., Wernli, R., 2005. Latest Burdigalian network of fluvial valleys in southeast France (western Alps): characteristics, geographic extent, age, implications. Comptes Rendus Geosciences 337 (12), 1045-1054.

Berggren, W.A., Hilgen, F.J., Langereis, C.G., Kent, D.V., Obradovich, J.D., Raffi, I., Raymo, M.E., Shackleton, N.J., 1995. Late Neogene chronology: New perspectives in high-resolution stratigraphy. Geological Society American Bulletin, 107, 1272-1287.

Bourcart, J., De La Bernardie, A., Lalou C., 1948. Le rech Lacaze-Duthiers, canon sousmarin du plateau continental du Roussillon, Comptes Rendus de l'Académie de Sciences 226 (20), 1632-1633. Clauzon, G., 1973. The eustatic hypothesis and the pre-Pliocene cutting of the Rhône valley. In: W.B.F. Ryan and K.J. Hsü, Editors, Initial Report of the Deep Sea Drilling Project, pp. 1251-1256. 
Clauzon, G., 1987. Neogene geodynamical evolution of a Pyreneo-Mediterranean Graben: the Roussillon example (southern France). Annals of the Hungarian Geological Institute 70, 221-226.

Cravatte, J., Dufaure, P., Prim, M. and Rouaix, S., 1974. Les sondages du Golfe du Lion : stratigraphie, sédimentologie, Notes \& Mémoires. Compagnies Françaises des Pétroles, pp. 209-274.

Dos Reis, A.T., 2001. La Tectonique Salifère et son Influence sur l'Architecture Sédimentaire Quaternaire de la Marge du Golfe du Lion - Méditerranée Occidentale. Thèse de Troisième cycle, University Pierre et Marie Curie - Paris VI, 373pp.

Dos Reis, A.T., Gorini, C., Mauffret, A., 2005. Implications of salt-sediment interactions on the architecture of the Gulf of Lions deep-water sedimentary systems-western Mediterranean Sea. Marine and Petroleum Geology 22 (6-7), 713-746.

Druckman, Y., Buchbinder, B., Martinotti, G.M., Siman Tov, R. and Aharon, P., 1995. The buried Afiq Canyon (eastern Mediterranean, Israel): a case study of a Tertiary submarine canyon exposed in Late Messinian times. Marine Geology 123, 167-185.

Duvail, C., Gorini, C., Lofi, J., Le Strat, P., Clauzon, G., Dos Reis, A.T., 2005. Correlation between onshore and offshore Pliocene-Quaternary systems tracts below the Roussillon Basin (eastern Pyrenees, France). Marine and Petroleum Geology 22 (6-7), 747-756.

Fulthorpe, C.S., Moutain, G.S. and Miller, K.G., 1996. Mapping the Neogene depositional geometries, New Jersey continental slope, LEG 150 drilling area. Proceedings of the Ocean Drilling Program, Scientific Results, 150, 269-281.

Fulthorpe, C.S., Austin, J.A., Moutain, G.S., 2000. Morphology and distribution of Miocene slope incisions off New Jersey: Are they diagnostic of sequence boundaries? Geological Society of America Bulletin 12 (6), 817-828.

Galloway, W.E., Dingus, W.F., Paige, R.E., 1991. Seismic and depositional facies of PaleoceneEocene Wilcox group submarine canyon fills, northwest Gulf Coast, U.S.A. In: P. Weimer and M.H. Link (Editors), Seismic facies and sedimentary processes of submarine fans and turibidite systems. Springer-verlag, New York. pp 247-271.

Gautier, F., Clauzon, G., Suc, J.P., Cravatte, J., Violanti, D., 1994. Age et durée de la crise de salinité messinienne. Compte Rendu de l'Académie des Sciences de Paris 318 (2), 1103-1109.

Gardner, J., Prior, D., Field, M., 1999. Humboldt Slide - a large shear-dominated retrogressive slope failure. Marine Geology, 154, 323-338

Gennesseaux, M., Lefebvre, D., 1980. Le Golfe du Lion et le Paléo-Rhône messinien. Géologie Méditerranéenne 7 (1), 71-80.

Gorini, C., 1993. Géodynamique d'une marge passive : le Golfe du Lion (Méditerranée occidentale). Thèse de Troisième cycle, University of Paul-Sabatier, Toulouse III, 256 pp.

Gorini, C., Le Marrec, A., Mauffret, A., 1993. Contribution to the structural and sedimentary history of the Gulf of Lions (Western Mediterranean), from the ECORS profiles, industrial seismic profiles and well data. Bulletin de la Société Géologique de France 164 (3), 353-363.

Gorini, C., Bache, F., Duvail, C., Dos Reis, A.T., Olivet, J.L., Rabineau, M., Lestrat, P., Lofi, J., Mauffret, A., Berné, S., 2003. Genetic model of deposition for the Miocene of the Gulf of Lions (western Mediterranean) from seismic stratigraphy and well log correlation. Eighth International Congress of The Brazilian Geophysical Society, Rio de Janeiro, Brazil.

Gorini, C., Lofi, J., Duvail, C, Dos Reis, T, Guennoc , P, Berné, S, Le Strat , P, Mauffret, A., 2005. The Late Messinian (5.6- $5.32 \mathrm{Ma}$ ) salinity crisis and Late Miocene tectonism : interaction and consequences on the physiography and post-rift evolution of the Gulf of Lions margin. Marine and Petroleum Geology 22 (6-7), 695-712.

Guennoc, P., Gorini, C., Mauffret, A., 2000. Histoire géologique du Golfe du Lion et cartographie du rift oligo-aquitanien et de la surface messinienne. Géologie de la France, 3, 67-97.

Hampton, M.A., 1996. Submarine slides. Reviews of Geophysics 34 (1), 33-59.

Haq, B.U., Hardenbol, J., Vail, P., 1987. Chronology of fluctuating sea-levels since Triassic (250 million years ago to present). Science 235 (4793), 1156-1167.

Hsü, K.J., Cita, M.B., Ryan, W.B.F., 1973. Origin of the Mediterranean evaporites. In: Ryan, W.B.F, Hsü, K.J., et al. (Eds.), Initial Reports of the Deep-Sea Drilling Project. U.S. Government Printing Office, Washington, DC, 13, 1203-1231

Krijgsman, W., Hilgen, F.J., Raffi, I., Sierro, F.J., Wilson, D.S., 1999. Chronology, causes and progression of the Messinian salinity crisis. Nature, 400, 652-655.

Lofi, J., 2002. La Crise de Salinité Messinienne : Incidences directes et différées sur l'évolution sédimentaire de la marge du Golfe du Lion, Thèse de Troisième Cycle, University of Lille I, 285pp. 
Lofi, J., Rabineau, M., Gorini, C., Berné, S., Clauzon, G., De Clarens, P., Moutain, G.S., Ryan, W.B.F., Steckler, M.S., Fouchet, C., 2003. Plio-Quaternary prograding clinoform wedges of the Western Gulf of Lions continental margin (NW Mediterranean) after the Messinian Salinity Crisis. Marine Geology 198 (3-4), 289-317.

Lofi, J., Gorini, C., Berne, S., Clauzon, G., Dos Reis, A.T., Ryan, W.B.F., Steckler, M., 2005. Paleoenvironmental changes and erosional processes on the western Gulf of Lions duringt he Messinian Salinity Crisis. Marine Geology 217 (1-2), 1-30.

Lofi, J. , Deverchère, J., Gaullier, V., Gillet, H., Guennoc, P., Gorini, P., Loncke, L., Maillard, A., Sage, F., Thinon, I., Capron, A., Obone Zue Obame, E, 2007. The Messinian Salinity Crisis in the offshore domain: an overview of our knowledge through seismic profile interpretation and multi-site approach. 33rd CIESM Workshop on "Messinian Evaporites - from Mega-deposits to Micro-biology". Alméria, Spain.

Maillard, A., Mauffret, A., 2006. Relationship between erosion surfaces and Late Miocene Salinity Crisis deposits in the Valencia Basin (northwestern Mediterranean): evidence for an early sea-level fall, Terra Nova 18, 321-329.

Mauffret, A., Durand de Groussouvre, B., Dos Reis, A.T., Gorini, C., Nercessian, A., 2001. Structural geometry in the eastern Pyrenees and Western Gulf of Lion (Western Mediterranean). Journal of Structural Geology 23, 1701-1726.

McAdoo, B.G., Pratson, L.F., Orange, D.L., 2000. Submarine landslide geomorphology, US continental slope. Marine Geology 169, 103-136.

McHargue, T.R., Webb, J.E., 1986. Internal geometry, seismic facies, and petroleum potential of canyons and inner fan channels of the Indus submarine fan. American Association of Petroleum Geologits Bulletin 70 (2), 161-180.

Miller, K.G., Melillo, A.J., Mountain, G.S., Farre, J.A., Poag, C.W., 1987. Middle to late Miocene canyon cutting on the New Jersey continental slope: Biostratigraphic and seismic stratigraphic evidence. Geology 15, 509-512.

Millot, C., 1999. Circulation in the Western Mediterranean Sea. Journal of Marine Systems, 20, 423442.

Mitchum, R. and Vail, P. (Editors), 1977. Seismic stratigraphy and global change of sea-level, part 7: Seismic Stratigraphic Interpretation Procedure. Seismic stratigraphy - Application to hydrocarbon exploration. American Association of Petroleum Geologists 26, 135-143.

Mountain, G.S., Damuth, J.E., McHugh, C.M.G., Lorenzo, J.M., Fulthrope, C.S., 1996. Origin, reburial, and significance of a Middle Miocene canyon, New Jersey continental slope. Proceedings of the Ocean Drilling Program, Scientific Results, 150, 283-292.

Normark, W.R., 1970. Growth patterns of deep-sea fans. American Association of Petroleum Geologists Bulletin 54, 2170-2195.

O'Connell, S., Ryan, W.B.F., Normark, W.R., 1987. Modes of development of slope canyons and their relation to channel and levee features on the Ebro sediment apron, offshore northeastern Spain. Marine and Petroleum Geology 4, 308-319.

Olabode, S.O., Adekoya, J.A., in press. Seismic stratigraphy and development of Avon canyon in Benin (Dahomey) basin, southwestern Nigeria. Journal of African Earth Sciences.

Pratson, L.F., Coakley, B.J., 1996. A model for the headward erosion of submarine canyons induces by downslope-eroding sediment flows. Geological Society American Bulletin 108, 225-234.

Rehault, J.P., Boillot, G., Mauffret, A., 1984. The Western Mediterranean Basin geological evolution. Marine Geology 55 (3-4), 445-475.

Ryan, W.B.F., 1976. Quantitative evaluation of the depth of the western Mediterranean before, during and after the late Miocene salinity crisis. Sedimentology 23 (6), 791-813.

Seranne, M., Camus, H., Lucazeau, F., Barbarand, J., Quinif, Y., 2002. Surrection et érosion polyphasée de la bordure cévenole. Un exemple de morphogénèse lente. Bulletin de la Société Géologique de France 173 (2), 97-112.

Shepard, F.P., 1981. Submarine canyons: multiple causes and long-time persistence. American Association of Petroleum Geologists Bulletin 65, 1062-1077.

Sage, F., Von Gronefeld, G., Déverchère, J., Gaullier, V., Maillard, A., Gorini, C., 2005. Seismic evidence for Messinian detrital deposits at the western Sardinia margin, northwestern Mediterranean. Marine and Petroleum Geology 22 (6-7), 757-773.

Smith, W., Sandwell, D., 1997. Global sea floor topography from satellite altimetry and ship depth soundings. Science 277, 1956-1962. 
Sultan, N., Gaudin, M., Berné, S., Canals, M., Urgeles, R., Lafuerza, S., 2007. Analysis of slope failures in submarine canyon heads: an example from the Gulf of Lions. Journal of Geophysical Research, 112, F01009.

Twichell, D.C., Robert, D.G., 1982. Morphology, distribution, and development of submarine canyons on the United States Atlantic continental slope between Hudson and Baltimore Canyons. Geology 10, 408-412.

Vail, P.R., Audemart, F., Bowman, S.A., Eisner, P.N., Perez-Cruz, G., 1991. The stratigraphic signatures of tectonics, eustasy and sedimentation- an overview. In: G. Einsele, W. Ricken and A. Seilacher (Editors), Cyclic stratigraphy. Springer-Verlag, New York, pp. 617-659.

Varnes, D.J., 1978. Slope movement types and processes. In: R.L. Schuster and R.J. Krizek (Editors), Landslides-Analysis and Control, Washington D.C., pp. 12-33.

Watkins, D.J., Kraft, L.M., 1978. Stability of continental shelf and slope off Louisiana and Texas: geotechnical aspects. In: A.H. Bouma, Moore, G.T. and Coleman,J.M. (Editor), Framework, facies, and Oil-trapping characteristics of the upper continental margin.

Williams, T.A., Graham, S.A., Constenius, K.N., 1998. Recognition of a Santonian Submarine Canyon, Great Valley Group, Sacramento Basin, California: implications for petroleum exploration and sequence stratigraphy of deep-marine strata. American Association of Petroleum Geologists 82 (8), 1575-1594.

\section{Figures}

Fig. 1. (A) Digital terrain model of the Western Mediterranean Sea (Smith and Sandwell, 1997) showing the location of the Gulf of Lions in the north-western part of the Provençal Basin. (B) Simplified bathymetric map (IFREMER) of the western Gulf of Lions showing location of the study area (black box), the grid of seismic lines and the exploratory wells. The heavy lines refer to the illustrations cited in the text. Messinian clastic deposits (unit CU) are after Lofi et al. (2005). Abbreviations are: LRF: Languedoc-Roussillon fan; RF: Rascasse fan. The initial onlap (before salt tectonics) of the Messinian salt in the deep basin is after Dos Reis (2001).

Fig. 2. (A) Line drawing of LRM10, Ligo22, ACHERE01, ACHERE02 (TOTAL) and Calmar67 (IFREMER) dip seismic lines illustrating the architecture of the Miocene-to-modern sediments on the western Gulf of Lions margin. At the bottom, the pre-rift basement is structured in horsts and grabens. The overlying Miocene sequence (Mio) is offset by a number of normal faults associated with a Upper Miocene extensional phase. This sequence is eroded at the top by the Messinian Margin Erosional Surface (MES) which correlates basinward with the deep basin evaporite sequence (LU: Lower Unit; MU: Mobile unit (salt); UU: Upper Unit). Messinian clastics (unit CU) are observed locally at the base of the thick Plio-Pleistocene prograding sequence (PP). Abbreviations are : RF: Rascasse Fan; CG: central graben; RH: Rascasse horst; BES: bottom erosional surface. See figure 1 for the location of the line drawing. (B) close-up view illustrating the sedimentary architecture over the study area. Two singular seismic bodies (C2 and C3) are visible in the Miocene sequence. They are eroded at the top by the MES and extend donwslope beneath CU. (C) Close-up view of C2 and C3 on an interpreted dip seismic profile (ACHERE02). C2 passes seawards to a transparent chaotic facies located beneath unit $\mathrm{CU}$. Beneath $\mathrm{C} 2$, recognisable main physiographic break in slope in the depositional profile between foresets and topsets are interpreted as Miocene offlap breaks, allowing to determine the position of shelf break

Fig. 3. Interpreted oblique seismic profile (Marion10, IFREMER) across the present day middle slope illustrating the existence of 3 superimposed Miocene seismic bodies labelled C2 to C4, eroded at the top by the MES. The erosional character of these bodies is outlined by the erosional or angular unconformities between the Miocene truncated seismic reflectors and the internal reflector geometry and/or seismic facies. Uninterpreted (Z1) and interpreted (Z2) close-up views of the black box clearly illustrate the surfaces of truncation (ES2 to ES4) that delineate the walls of these seismic bodies. ES3 displays a concave upward shape whereas ES 2 is wavy. Seismic facies in C2 is chaotic to transparent. C3 and C4 contain relatively well-organised groups of continuous to sub-continuous, sub- 
parallel reflections. Intercalated transparent or chaotic levels are visible locally. See position in figure 1.

Fig. 3. Interpreted oblique seismic profile (Marion10, IFREMER) across the present day middle slope illustrating the existence of 3 superimposed Miocene seismic bodies labelled C2 to C4, eroded at the top by the MES. The erosional character of these bodies is outlined by the erosional or angular unconformities between the Miocene truncated seismic reflectors and the internal reflector geometry and/or seismic facies. Uninterpreted (Z1) and interpreted (Z2) zooms of the black box clearly illustrate the surfaces of truncation (ES2 to ES4) that delineated the walls of these seismic bodies. ES3 displays a concave upward scoop shape whereas ES 2 is wavy. Seismic facies in C2 is chaotic to transparent. C3 and C4 contain relatively well organised groups of continued to sub-continue, subparallel reflections. Intercalated transparent or chaotic levels are visible locally. See figure 1 for the location of the profile.

Fig. 4. Interpreted dip seismic profile (ACHERE06, TOTAL) across the present day middle slope, illustrating in cross section the Messinian clastics (Unit $\mathrm{CU}$ ) of the Languedoc-Roussillon detrital fan accumulated in a Messinian valley. Three Miocene seismic bodies are evidenced further downslope and labelled C3 to C5. Uninterpreted (Z1) and interpreted (Z2) close-up views of the black box illustrate the detailed organisation and internal structure of C3, C4 and C5. They are delineated by surfaces of truncation labelled ES3 to ES 5 respectively. Internal discontinuities are visible locally within $\mathrm{C} 5$. The landward extension of these surfaces beneath $\mathrm{CU}$ cannot be traced with confidence. See position in figure 1.

Fig. 5. Top: map showing the areal distribution of Miocene erosional systems evidenced over the study area. Bold lines illustrate the location of the surfaces of truncation (ESs) that delineate the walls of the systems. Dashed bold lines show possible (extrapolated or speculated) boundaries of the erosional systems in areas where seismic data did not allow confident interpretation (e.g. beneath the Messinian clastics (CU) mapped in dark grey color, and extending beneath the Messinian salt unit). This map suggests a global south-eastward migration of the systems in time, from the oldest (C1) to the most recent one (C5). Arrows indicate the interpreted direction of system elongation/axes. See figure 1 for location of the map.

Bottom: seismic facies identified in the seismic bodies (letters refers to the location on the map). Facies A and B contain groups of reflections that are poorly organised with an overall chaotic character. Facies C, D, E show relatively well organised groups of continuous to sub-continuous reflections.

Fig. 6. Interpreted strike seismic profile (ACHERE11, TOTAL) across the present-day lower slope. To the S-SW, unit CU fills the Rascasse Messinian valley (Fig. 1) and shows a chaotic seismic facies. Beneath $\mathrm{CU}$, the seismic facies is more transparent. Uninterpreted (Z1) and interpreted (Z2) close-up view (black box) illustrates, in cross section, the morphology of the superimposed Miocene seismic bodies C3, C4 and C5. C5 is the youngest system mapped over the study area. The eastward extension of these systems cannot be traced on the seismic profile.

Fig. 7. Interpreted strike seismic profile (ACHERE7, TOTAL) across the present day middle slope illustrating, in cross section, Miocene seismic body $\mathrm{C} 1$ in its upslope part. Uninterpreted (Z1) and interpreted (Z2) close-up view (black box) illustrating the complex displays chaotic internal seismic facies. $\mathrm{C} 1$ extends to the NE beneath $\mathrm{CU}$ which belongs to the Messinian Languedoc-Roussillon fan system.

Fig. 8. Interpreted strike seismic profile (ACHERE9, TOTAL) across the present day middle slope illustrating, in cross section, the shape of the Miocene seismic bodies C1 and C2. Uninterpreted (Z1) and interpreted (Z2) close-up views of the black box illustrating the complex organisation of the internal seismic reflectors within C2. Diachronic v-shaped reflector packages suggest lateral accretion within a canyon head as it migrated to the SW and eroded the opposite wall. Aggradation is visible in the topsets of the eastern wall of $\mathrm{C} 2$. 
Fig. 9. Chrono-stratigraphy (Berggren et al., 1995) matched against long-term and short-term eustatic curves (Haq et al., 1987) and against the main tectonic and sedimentary events that occurred in the Gulf of Lions. The proposed potential time-window for Miocene submarine canyon development is 16.4 - 5.6 Ma. The Upper Miocene tectonic extensional phase and the Tortonian regression (between 11.2 and $7.12 \mathrm{Ma}$ ) are the two best candidates (triggering events,TE) for canyon initiation. 


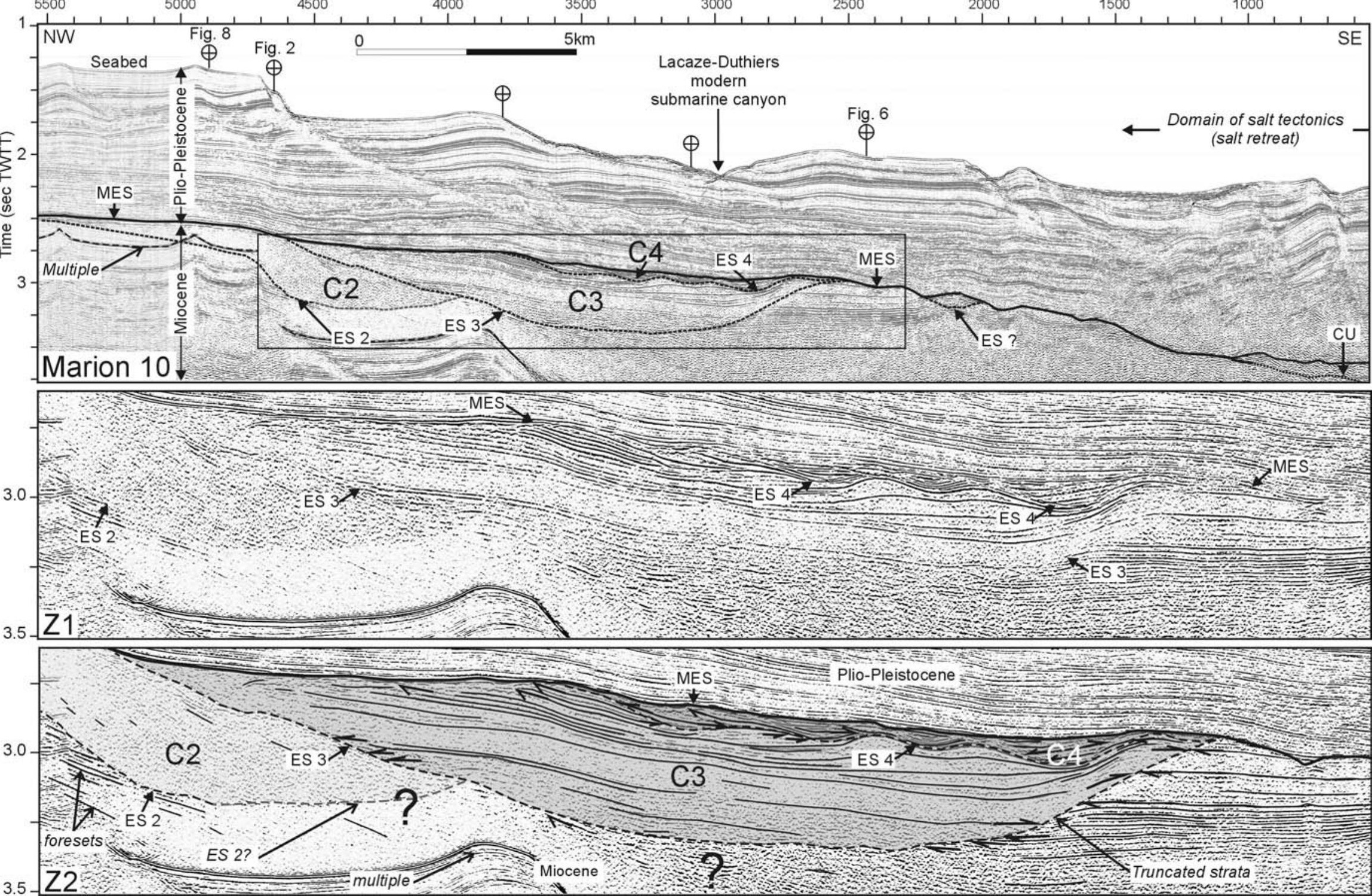



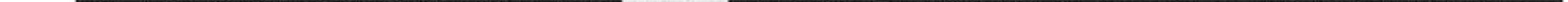


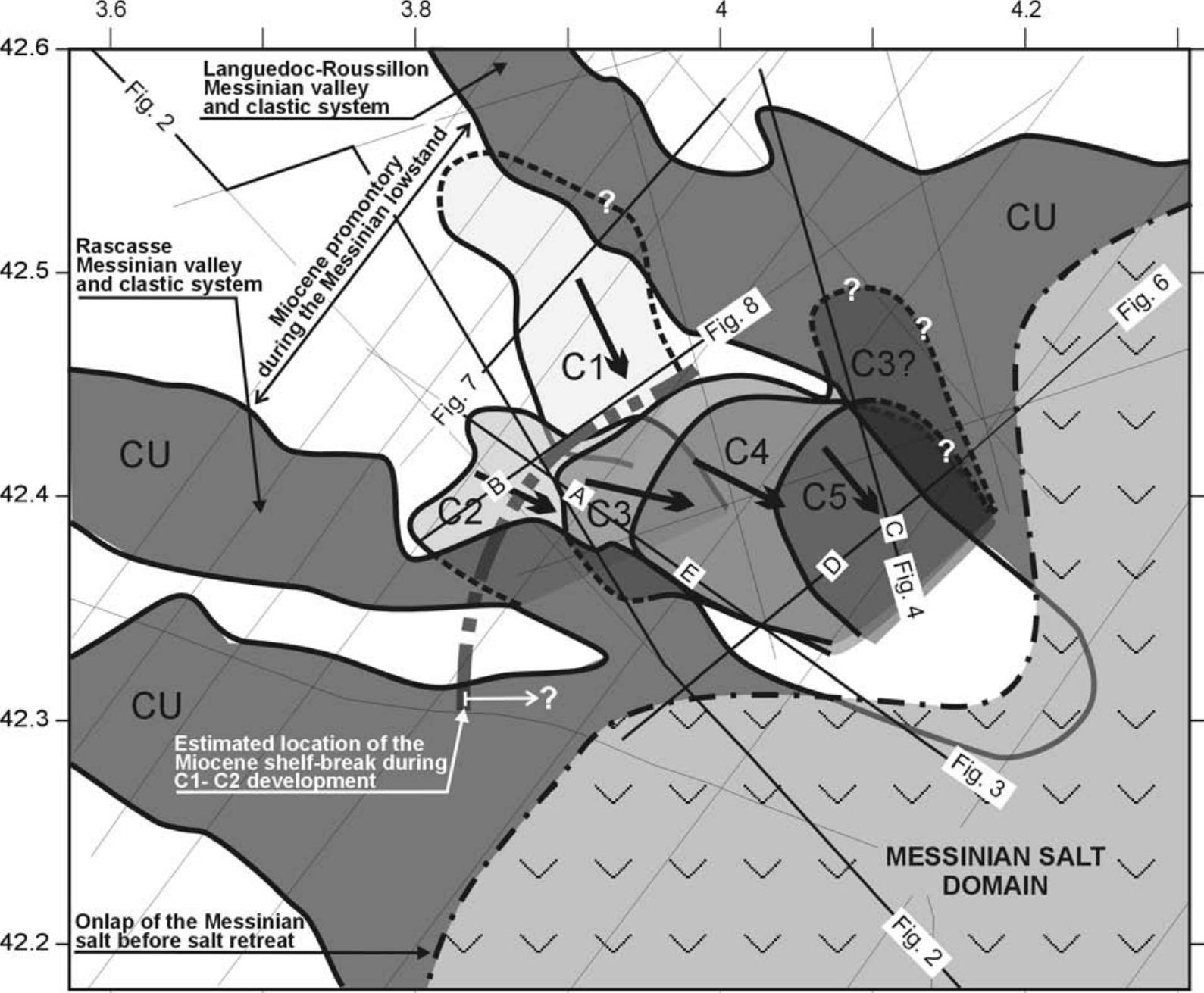

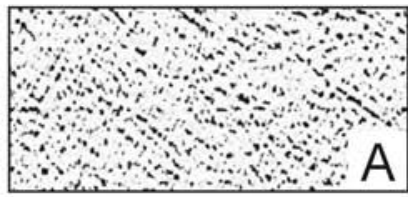

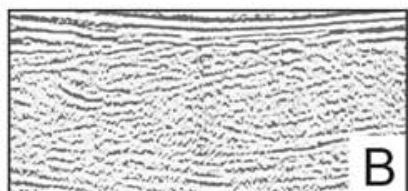

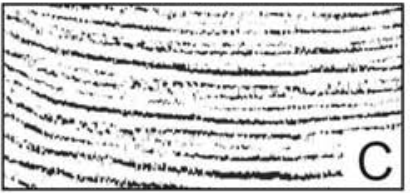

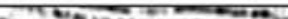

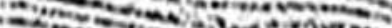

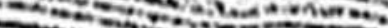

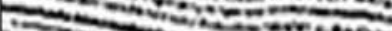

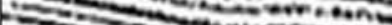
\%

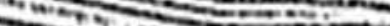

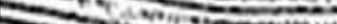

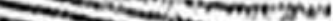

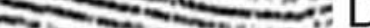

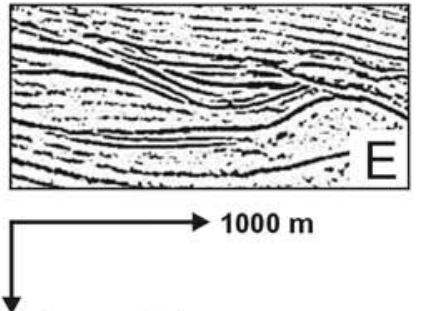

$100 \mathrm{msec}$ TWTT 

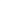

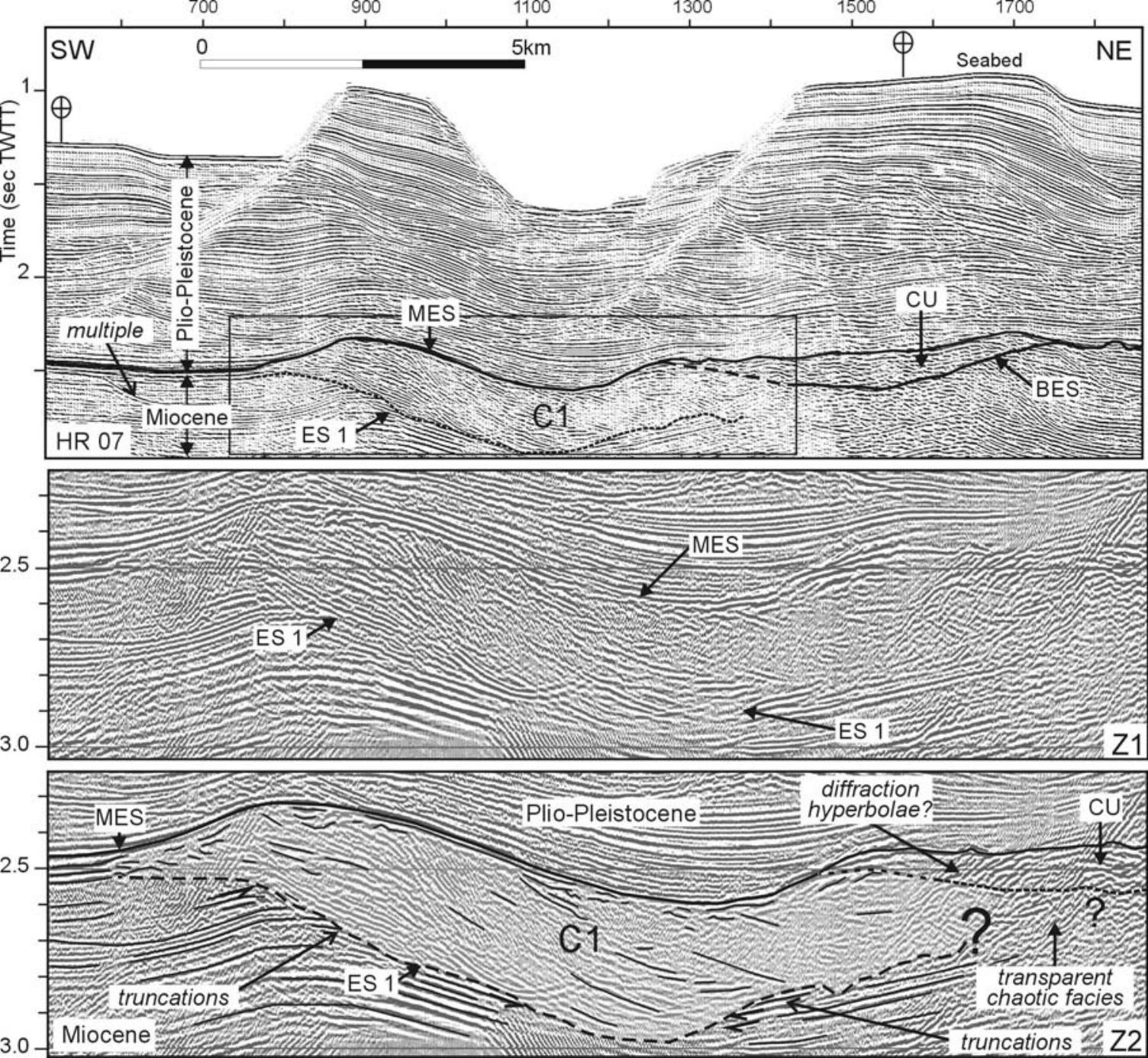


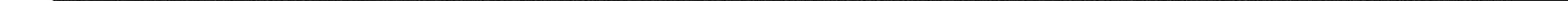




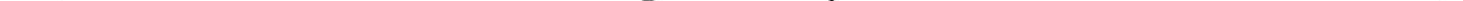

